\title{
Christmas White Paper
}

\author{
Stephen Hancocks OBE \\ Editor-in-Chief
}

The BDJ Upfront section includes editorials, letters, news, book reviews and interviews. Please direct your correspondence to the News Editor,

Kate Quinlan at BDJNews@nature.com. Press releases or articles may be edited, and should include a colour photograph if possible.

$\mathrm{N}$

ot surprisingly, many White Papers emanating from Whitehall cause only passing interest in the media before sinking into obscurity in the parliamentary system. Exceptions are when a particular subject area is of direct relevance to an individual or group and in this instance there can be fewer matters of greater relevance to virtually the entire UK population than yuletide. Consequently, the government's recent Christmas White Paper on the future of this traditional celebration cannot fail to have touched each and every one of us either privately or professionally in its ramifications.

The main proposal, as most readers will by now be aware, is to make Christmas a moveable feast by phasing it throughout the year, thereby reducing the pressure on various public services, particularly the NHS, which are especially felt in mid to late December. The plan would be to divide the UK into twelve Christmas divisions, or Carols. Christmas would then be celebrated sequentially in each of the Carols, beginning from the northernmost in Scotland in January where, due to the weather, it would still feel like the traditional festival and moving steadily southwards in monthly stages until it reached Devon and Cornwall in December.

This is a radical suggestion but an evidencebased one founded on Treasury statistics which show that staggering the celebrations would spread the demand for medical treatment in particular but also dental and social services by enabling staff to be moved to various Carols when needed without the expense of overtime. Of course staff being redeployed in this way would not be allowed to actually celebrate Christmas in the area in which they are allocated duties and would only be permitted to celebrate in their own designated Carol. It is easy to see how this may cause confusion and indeed is one of the administrative points noted in the White Paper for discussion and already raised by many commentators. The need for a whole new tier of management tasked with issuing celebratory permits would lessen the potential saving to the taxpayer as well as causing possible ill will to those who wish to mark the festival in the Carol of their choosing.

By the same token families and friends will have to indicate at least 12 months in advance as to whether or not they wish to travel into a celebratory zone during that Carol's designated yuletide month. In this regard people with caravans will come under particularly close scrutiny to prevent them partying the whole year long whilst motoring southwards.

These social issues aside, as far as dentistry goes the scheme has both advantages and potential drawbacks. On the plus side, the need for team members all wanting to take irritating extra level of bureaucracy.

Retailers have provisionally welcomed the proposals although those with online businesses have questioned the practicality of restricting buyers to specific Carols at particular times and queried the way in which 'January' sales might operate under the scheme. This, given that January would follow Christmas only in the Highlands, August following it in Bedfordshire for example.

Much thought still needs to go into the feasibility of the proposals and, even if eventually enacted, they are unlikely to come into being until 2023 at the earliest. Readers are urged to respond to the document through the usual government channels, via websites or their local Members of Parliament. The closing date is midsummer's day 2017 (Christmas Eve

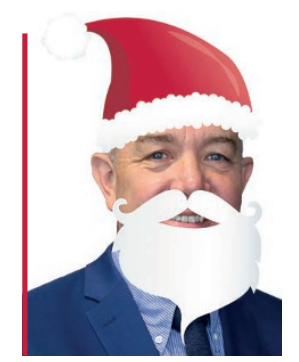

\section{'The proposal is to make Christmas a moveable feast to reduce pressure on the NHS...'}

holidays on or around 25 December will be dissipated; those visiting relatives in Yorkshire for Christmas, for example, asking for leave on and around 25 April. Similarly, the need for emergency cover in, say, Hampshire will be at a much more convenient time in the vicinity of 25 October. Conversely, one can foresee problems arising when urgent orders for practice consumables need to be placed with, perhaps, a supplier in Wales at a time when the Welsh Carol is in session meaning an unavoidable delay to delivery. Similarly, a dentist treating a patient celebrating Christmas whilst outside their Carol of residence during that Carol's designated yuletide slot would need to claim for an additional emergency fee quoting the patient's permit number; obviously an in future in Droitwich if the proposals become law). The result of the referendum in June this year in which the UK voted to leave the EU will have no effect on the proposals since European countries will continue to celebrate Christmas in the month of their choosing. Although this may also add a further layer of confusion since visitors from $\mathrm{EU}$ countries will only be allowed to stay in one 'single preference' Carol each twelve months.

Please accept my good wishes and those of the whole team here at the $B D J$ for a Merry Christmas and Happy, Healthy and Prosperous New Year. We hope that you enjoy our tongue in cheek seasonal content in this Christmas issue.

DOI: $10.1038 /$ sj.bdj.2016.928 